
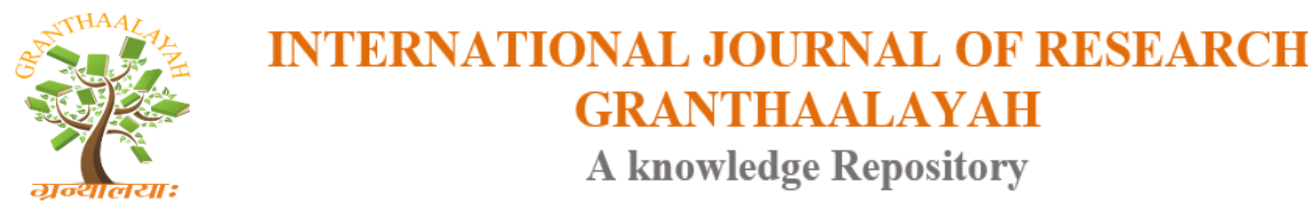

Social

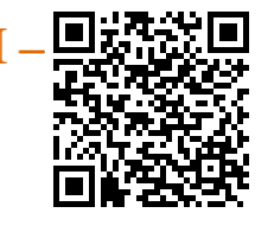

\title{
A FIELD STUDY ON THE REASON TO CHOOSE THE PROGRAMME, MOTIVES, PREPAREDNESS TO UNIVERSITY EDUCATION AND ACADEMIC PERFORMANCE OF ACCOUNTING PROGRAMME STUDENTS
}

\author{
Zeynep Hatunoğlu ${ }^{1}$, Ahmet Kaya ${ }^{2}$, Filiz Angaykutluk *3 \\ ${ }^{1}$ Kahramanmaras Sutcu Imam University, Kahramanmaras, Turkey \\ 2, 3 Akdeniz University, Antalya, Turkey
}

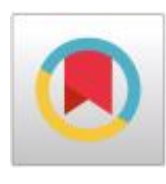

\begin{abstract}
This paper examines the perceptions of first-year students (freshmen) of accounting at Akdeniz University (AU) and Kahramanmaras Sutcu Imam University (KSU) to explore a range of factors which impact on students' learning: their motives for entering higher education, their rationale for selecting an accounting programme, their preparedness for further study and their expectations. The study also explores the influence of these antecedent variables on academic performance in the first accounting module. Data was collected from 420 accounting students in first year classes at the AU and KSU. The data required for this study was collected via a questionnaire which was developed by Byrne and Flood in 2005 known as the Motives, Expectations and Preparedness for University (MEPU) questionnaire. Results show that there is a relation between interest in accounting as professional career and accounting first grade. First semester average mark shows positively that the willingness of accounting as a career influence the grades positively. KSU students rated higher than AU students in some statements of motives for attending university, preparedness for university, reason for choosing accounting programme. It can also be said that female students and KSU students have stronger motives and higher expectations for entering higher education.
\end{abstract}

Keywords: Accounting Education; Higher Education; Academic Performance; Motives.

Cite This Article: Zeynep Hatunoğlu, Ahmet Kaya, and Filiz Angaykutluk. (2018). "A FIELD STUDY ON THE REASON TO CHOOSE THE PROGRAMME, MOTIVES, PREPAREDNESS TO UNIVERSITY EDUCATION AND ACADEMIC PERFORMANCE OF ACCOUNTING PROGRAMME STUDENTS." International Journal of Research - Granthaalayah, 6(11), 209-221. https://doi.org/10.29121/granthaalayah.v6.i11.2018.1119.

\section{Introduction}

In developed nations, it can be seen that accounting education has received much attention from researchers and there are a good number of studies about accounting education and how it might be enhanced. But the research on accounting education in developing countries is still far behind; 
various factors such as culture, politics, and social factors affect their education systems. So, because different nations have their unique features, and results from accounting education studies can not be always applied to them (Al-Twaijry, 2010, 311).

According the Higher Education Law enacted in 1981, in Turkish higher education system, it was aimed to determine the purpose and principles related to higher education and to regulate the organization, operation, duties, powers and responsibilities of all higher education institutions (article 1). Turkey has been included to Bologna process since 2001 (Çelik, 2012, 101). Bologna process has been commenced by 29 European countries in 1999, and its goals are to create an European Higher Education Area which targets to extend the mobility of students education staff, to develop the role and efficiency of Europe in Higher Education. It also aims to apply European Credit Transfer System to form comparable and understandable diplomas and grades, and quality assurance systems in higher education.

One of the most important conditions for ensuring quality in higher education is to respond the students' demands and expectations completely. Could not responding the students' demands and expectations will return frustration and failure, and this case will prevent the achievement of the desired quality. At this point, it is needed to determine the expectations and motivations of students (Zeytinoglu, 2012, 104).

Zeytinoglu $(2012,104)$ states that several research had been done about the transition process from secondary education to higher education, and motivations, expectations, preparedness, causes of selecting the department and academic performance of students. Zeytinoglu $(2012,106,113)$ made an investigation in order to determine how much confidence accounting department students have, how much they are prepared to higher education, how much motivation they have for university education and their expectations from higher education. According to research results, it was determined that education level and career opportunities of the future are motivators, and the most remarkable expectations of students are listed as to increase self-confidence and to be able to get new ideas.

Byrne and Flood (2008, 202) examined associations between motivations, expectations, preparedness for higher education, gender, prior knowledge of accounting and prior academic achievement and academic performance of the first year accounting students. Results showed that there were association between academic performance, prior knowledge of accounting and prior academic achievement.

Arquero and the others $(2009,279,294)$ had examined the motives, expectations and preparedness of entry level Business Management students at a Spanish university to explore the relationship of these factors with their academic performance in the first accounting module. Results showed that the programme was the first choice for most of the students, and more than half of the students were interested in a career in accounting. The factors significantly correlated with performance were interest in accounting, experience of the subject at school, academic self-confidence and university access scores.

Byrne and Flood $(2005,120)$ investigated the motives, preparedness and expectations of Irish accounting students. According to the results, the main reasons of choosing to go to university 
were career and educational aspirations (p.115). Students mostly believed that they were well prepared for their higher education studies and majority of them were confident of their success (p.121).

In another study Byrne and Flood (2007, 45) examined the international business students' perceptions of motives for entering higher education, expectations and preparedness for degree programmes and commitment to their studies. This paper aims to examine international business students' perceptions of these variables. Results showed that international business students are motivated to enter higher education and feel well prepared for their university studies and were confident to succeed their studies (p.54).

Ozturk and Ilıman $(2015,79)$ aimed to determine the undergraduate students' reasons of choosing the programme, expectation and motivation levels and satisfaction levels from the programme who were attending to Gazi University Health Institutions Management Programme and Ankara University Health Institutions Management Programme. The results of the study showed that almost half of the students were satisfied from their universities and programmes, the most important reason choosing the programme was the expectancy to find a job after graduation. There was a strong relation between expectancy and motivation and there was a significant relation between students' satisfaction levels and expectancy and motivation levels (Ozturk ve Ilıman, 2015, 90-92).

Gencturk (2007, 179) investigated student performance in financial accounting course in vocational high schools. He found that graduates of commercial high schools were more successful than graduates of other high schools, and prior accounting knowledge influenced the success in accounting lessons in vocational high schools (p.183-184).

The aim of this study is to determine the motivation levels, expectations from higher education, reason to choose the programme, preparedness of university education, expectations from university education and academic confidences of the students who are attending Accounting and Tax Applications Programme at Vocational High Schools in Kahramanmaras Sutcu Imam University (KSU) and Akdeniz University (AU) in Turkey.

\section{Materials and Methods}

The data required for this study was collected via a questionnaire. Questionnaire used to gather most of the data in this study was developed by Byrne and Flood in 2005. A Spanish version of the Motives, Expectations and Preparedness for University (MEPU) questionnaire which was used by Byrne and Flood (2007) and then by Arquero and the others in 2009, includes both closed and open-end questions. Closed items are answered using a five-point Likert scale. Mann Whitney-U tests are used whether there are significant differences between students' gender or school and their motives, expectation, preparedness and academic performances.

The sampling frame contained for this study is defined as junior level students at Accounting and Tax Applications Programme at Vocational High Schools in Kahramanmaras Sutcu Imam University and Akdeniz University in Turkey. The questionnaire (Byrne and Flood, 2005) contains six general sections including both closed and open-end questions: The first section sought 
information about the demographic characteristics of students in the variables of gender, age, graduated high school, grade of accounting lecture and the factor influenced their decision to attend to university and the others. The second section investigated students' motivation factors for entering university. The third section examined students' perceptions on their preparedness for university. The fourth section explores their reasons for selecting accounting programme. The fifth section sought the students' expectations from education and the last section investigates their confidence in their ability to do well in their studies. On the last five sections, a Likert Scale was used. Participants were asked to indicate the level of assessments (perception) by choosing one of five possible responses, "strongly disagree", "disagree", "neutral", "agree" or "strongly agree". The questionnaire was applied to 680 students and 420 usable responses were analyzed. So a response rate of $61,7 \%$ has been reached.

\section{Results and Discussions}

Results are held in seven sections: In the first section, the results of some demographical characteristics and interest in Accounting as professional career were sought. In the second, section, the evaluation of the motives of Accounting Students for attending university was investigated. In the third section, the evaluation of preparedness of students for university was examined. In the fourth section, the evaluation of the reason for choosing accounting programme was sought. In the fifth section, the evaluation of expectations from university education was analyzed. In the sixth section, the evaluation of students' academic confidence was examined. In the last section (section 7), the result of correlation analysis of Gymnasium graduation grade, interest in pursuing an accounting career and programme first semester average mark of students from financial accounting 1 lecture was explained.

\subsection{Demographical Characteristics and Interest in Accounting as Professional Career}

The most remarkable percents of demographical characteristics of the participants are shown below in Table 1, while some of the percents of demographical characteristics are just explained, but not included in the Table. The frequencies of interest in accounting as professional career are shown in Table 2.

Table 1: Characteristics of Demographic Trends

\begin{tabular}{|c|c|c|c|}
\hline Gender & $\%$ & High School Gradua. Degree & $\%$ \\
\hline Female & 54,8 & 2 & 5,0 \\
\hline Male & 45,2 & 3 & 43,3 \\
\hline Graduated High Cchool & $\%$ & 4 & 45,0 \\
\hline Regular & 41 & 5 & 6,7 \\
\hline Vocational & 51,7 & Age & $\%$ \\
\hline Anatolian & 7,3 & $17-19$ & 41,7 \\
\hline School & $\%$ & $20-22$ & 49,5 \\
\hline Akdeniz Universtiy & 41,6 & $23-25$ & 5,5 \\
\hline Kahramanmaras Sutcu Imam University & 58,4 & $>26$ & 3,3 \\
\hline
\end{tabular}


According to Table 1, most of the students are female (54,8\%), 20-22 years old (49,5\%), graduated from vocational high school $(51,7 \%)$ and graduated with high school graduation degree of $4(45 \%)$. (The highest mark is 5)

Besides the Table 1, some of the demographic characteristics show that most of the participant students are educating at Akdeniz University. 54,8\% of students have a passing grade (between CC and AA) and, 63,6\% have CC (2) or a better grade as first semester mark. 53,6\% of the students study for the lessons less than 2 hours in a week, 33,6\% of students don't participate to any sport or hobby activities and $45,0 \%$ of them participate to some sport or hobby activities 1-3 hours in a week. 58,3\% of the students decide on the university because of their family advice. In Öztürk and Ilıman (2015)'s study, the most important reason choosing the programme was the expectancy to find a job after graduation.

Table 2: Interest in Accounting as Professional Career

\begin{tabular}{|l|l|}
\hline Variable & Percentages \% \\
\hline No interest & 7,4 \\
\hline Little interest & 14,0 \\
\hline Indifferent/ don't know yet & 21,9 \\
\hline Interest & 44,0 \\
\hline Very interest & 12,6 \\
\hline
\end{tabular}

Table 2 shows that just over $56 \%$ of participants were 'interested' or 'very interested' in an accounting career, while only $21,4 \%$ of students have 'little or no interest'.

To explore whether there is difference between gender and students' interest in accounting as a professional career, Mann Whitney-U test was conducted.

Table 3: Mann Whitney-U Test between Gender or School and Interest in Accounting as Professional Career

\begin{tabular}{ccccccc}
\hline Items & Gender/School & $\mathbf{N}$ & Mean & $\mathbf{U}$ & $\mathbf{Z}$ & $\mathbf{P}$ \\
\hline Interest in Accounting as Professional Career & $\mathrm{M}$ & 190 & $\mathbf{2 1 5 , 6 2}$ & 20877,0 & $-0,829$ &, 407 \\
& $\mathrm{~F}$ & 230 & 206,27 & & & \\
& & & & & & \\
Interest in Accounting as Professional Career & $\mathrm{KSU}$ & 175 & $\mathbf{2 3 2 , 9 1}$ & 17516,0 & $-3,372$ &, $001^{*}$ \\
& $\mathrm{AU}$ & 245 & 194,49 & & & \\
\hline
\end{tabular}

$* \mathrm{P}<0,05$

Mann Whitney $U$ test failed to identify any gender differences. According to Table 3, it can be seen that Akdeniz University students have less interest in an accounting career.

\subsection{Evaluation of the Motives of Accounting Students for Attending University}

Students mostly agree with the statements of "I believe that a university degree will open up new opportunities for me in the future" ( $\overline{\mathrm{X}}=4,29)$, "I want to become a better educated person" $(\overline{\mathrm{X}}=4,24)$, 
"I believe that university will give me the opportunity to improve my self-belief and selfconfidence" $(\overline{\mathrm{X}}=4,04)$.

To explore whether there are significant difference between gender and motivation factors of accounting students to attend university, Mann Whitney-U test was conducted in Table 4.

Table 4: Mann Whitney-U Test between gender and motives for entering higher education

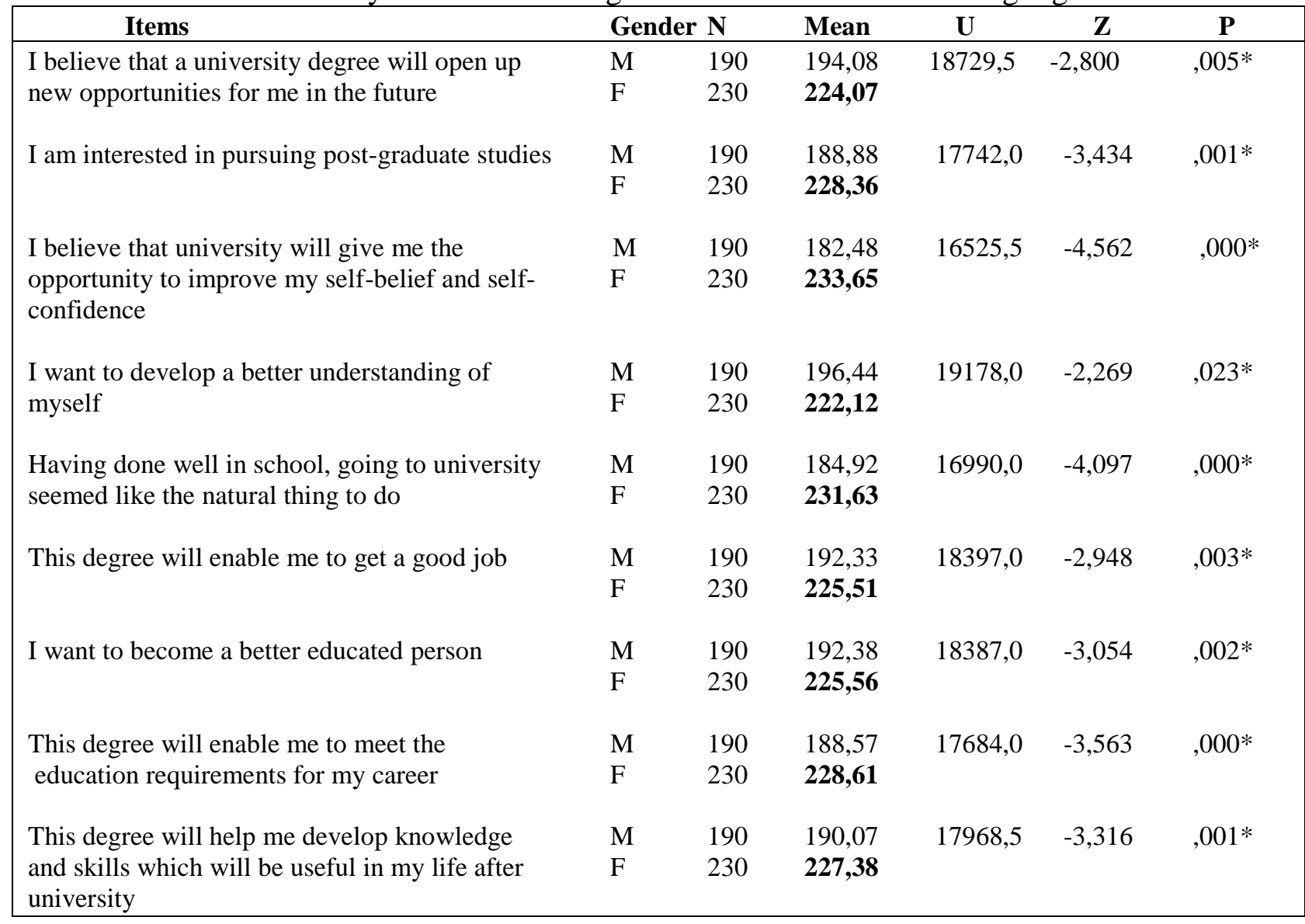

$* \mathrm{P}<0,05$

According to Table 4, there are differences between "gender" and female students agree more with the statements of "I believe that a university degree will open up new opportunities for me in the future", "I am interested in pursuing post-graduate studies", "I believe that university will give me the opportunity to improve my self-belief and self-confidence", "I want to develop a better understanding of myself", "Having done well in school, going to university seemed like the natural thing to do", "This degree will enable me to get a good job", "I want to become a better educated person", "This degree will enable me to meet the education requirements for my career" and "This degree will help me develop knowledge and skills which will be useful in my life after university". Students also agree more with the statements of "I believe that a university degree will open up new opportunities for me in the future" and "I believe that university will give me the opportunity to improve my self-belief and self-confidence". These results have similarities with Arquero and the others (2009)'s study. 
To determine whether there are significant differences between school and motivation factors of accounting students to attend university, Mann Whitney-U test was conducted in Table 5.

Table 5: Mann Whitney-U Test between school and motives for entering higher education

\begin{tabular}{|c|c|c|c|c|c|c|}
\hline Items & School & $\mathbf{N}$ & Mean & $\mathbf{U}$ & $\mathbf{Z}$ & $\mathbf{P}$ \\
\hline I wished to study Accounting in anin-depth way & $\begin{array}{l}\text { KSU } \\
\text { AU }\end{array}$ & $\begin{array}{l}175 \\
245\end{array}$ & $\begin{array}{l}\mathbf{2 2 4 , 3 1} \\
200,63\end{array}$ & 19020,0 & $-2,034$ &, $042 *$ \\
\hline $\begin{array}{l}\text { I want the chance to broaden my horizons and } \\
\text { face new challenges }\end{array}$ & $\begin{array}{l}\mathrm{KSU} \\
\mathrm{AU}\end{array}$ & $\begin{array}{l}175 \\
245\end{array}$ & $\begin{array}{l}\mathbf{2 2 7 , 3 3} \\
198,48\end{array}$ & 18493,0 & $-2,543$ &, $011^{*}$ \\
\hline $\begin{array}{l}\text { I believe that university will give me the } \\
\text { this opportunity to improve my self-belief and } \\
\text { self- confidence }\end{array}$ & $\begin{array}{l}\text { KSU } \\
\text { AU }\end{array}$ & $\begin{array}{l}175 \\
245\end{array}$ & $\begin{array}{l}\mathbf{2 2 3}, \mathbf{7 7} \\
201,02\end{array}$ & 19114,5 & $-2,009$ &, $045^{*}$ \\
\hline $\begin{array}{l}\text { I want to develop a better understanding of } \\
\text { myself }\end{array}$ & $\begin{array}{l}\text { KSU } \\
\text { AU }\end{array}$ & $\begin{array}{l}175 \\
245\end{array}$ & $\begin{array}{l}\mathbf{2 2 5 , 7 0} \\
199,64\end{array}$ & 18778,0 & $-2,280$ &, $023 *$ \\
\hline I want to become a better educated person & $\begin{array}{l}\mathrm{KSU} \\
\mathrm{AU}\end{array}$ & $\begin{array}{l}175 \\
245\end{array}$ & $\begin{array}{l}\mathbf{2 2 3 , 8 1} \\
200,99\end{array}$ & 19108,0 & $-2,074$ &, $038 *$ \\
\hline $\begin{array}{l}\text { This degree will help me develop knowledge } \\
\text { and skills which will be useful in my life after } \\
\text { University }\end{array}$ & $\begin{array}{l}\text { KSU } \\
\text { AU }\end{array}$ & $\begin{array}{l}175 \\
245\end{array}$ & $\begin{array}{l}\mathbf{2 2 3 , 8 7} \\
200,95\end{array}$ & 19097,5 & $-2,018$ &, $044^{*}$ \\
\hline $\begin{array}{l}\text { Coming to university affords me three more } \\
\text { years to decide what I really want to do }\end{array}$ & $\begin{array}{l}\mathrm{KSU} \\
\mathrm{AU}\end{array}$ & $\begin{array}{l}175 \\
245\end{array}$ & $\begin{array}{l}\mathbf{2 2 3 , 6 7} \\
201,09\end{array}$ & 19132,5 & $-1,970$ &, $049 *$ to \\
\hline
\end{tabular}

$* \mathrm{P}<0,05$

According to Table 5 there are differences between "school" and the statements of "I wished to study Accounting in an in-depth way", "I want the chance to broaden my horizons and face new challenges", "I believe that university will give me the opportunity to improve my self-belief and self-confidence", "I want to develop a better understanding of myself", "I want to become a better educated person", "This degree will help me develop knowledge and skills which will be useful in my life after university", "Coming to university affords me three more years to decide what I really want to do". Kahramanmaras Sutcu Imam University students agree more with the mentioned statements.

\subsection{Evaluation of the Preparedness of Students for University}

Students mostly agree with the statements of "Being able to organize your own life generally" $(\bar{X}=4,20)$, "Being able to evaluate your own progress" $(\bar{X}=3,97)$, "Being confident about your ability to complete written assignments (essays and projects)" ( $\overline{\mathrm{X}}=3,94)$.

To determine the significant differences between gender or school and the preparedness of accounting students for university, Mann Whitney-U test was conducted in Table 6 and Table 7.

Table 6: Mann Whitney-U Test between gender and preparedness of students for university

\begin{tabular}{|cllllll|}
\hline Items & Gender & $\mathbf{N}$ & Mean & U & Z & P \\
\hline Being willing to ask for help from your & M & 190 & 195,02 & $18909,5-2,426$ &, $015^{*}$ &
\end{tabular}


[Angaykutluk et. al., Vol.6 (Iss.11): November 2018]

(Received: October 14, 2018 - Accepted: November 19, 2018)

lecturers/tutors

F $\quad 230$

Being confident about your ability to complete assignments (essays and projects)

Being able to evaluate your own progress
ISSN- 2350-0530(O), ISSN- 2394-3629(P)

DOI: 10.5281/zenodo.1928219

222,43

M $\quad 190 \quad 192,38 \quad 18408,0 \quad-2,924,003 * \quad$ written

F $230 \quad \mathbf{2 2 5 , 4 7}$

M $\quad 190 \quad 194,62 \quad 18833,5-2,580 \quad, 010 *$

F $\quad 230 \quad \mathbf{2 2 3 , 6 2}$

$* \mathrm{P}<0,05$

According to Table 6, there are differences between "gender" and the statements of "Being willing to ask for help from your lecturers/tutors", "Being confident about your ability to complete written assignments (essays and projects)" and "Being able to evaluate your own progress". Female students agree more with the mentioned statements. Female students also agree more with the statement of "Being able to evaluate your own progress". This result has similarites with Arquero et al. (2009)'s study.

Table 7: Mann Whitney-U Test between school and preparedness of students for university

\begin{tabular}{|llllllc|}
\hline \multicolumn{1}{|c}{ Items } & School & N & Mean & U & Z & P \\
\hline $\begin{array}{l}\text { Being able to plan your study in a time } \\
\text { effective manner to meet all your deadlines }\end{array}$ & KSU & 175 & $\mathbf{2 2 5 , 7 9}$ & 18762,5 & $-2,297$ &, $022^{*}$ \\
& AU & 245 & 199,58 & & & \\
Being willing to ask for help from your & KSU & 175 & $\mathbf{2 2 8 , 2 1}$ & 18164,0 & $-2,742$ &, $006^{*}$ \\
this lecturers/tutors & AU & 245 & 196,94 & & & \\
& & & & & &, $003^{*}$ \\
Being confident about your ability to complete & KSU & 175 & $\mathbf{2 3 0 , 6 1}$ & 17918,5 & $-3,018$ & \\
written assignments (essays and projects) & AU & 245 & 193,81 & & & \\
& & & & & & \\
Being willing to participate in class & KSU & 175 & $\mathbf{2 3 0 , 9 0}$ & 17867,5 & $-3,047$ &, $002^{*}$ \\
& AU & 245 & 195,93 & & & \\
\hline
\end{tabular}

$* \mathrm{P}<0,05$

According to Table 7 there are differences between "school" and the statements of "Being able to plan your study in a time effective manner to meet all your deadlines", "Being willing to ask for help from your lecturers/tutors", "Being confident about your ability to complete written assignments (essays and projects)" and "Being willing to participate in class". Kahramanmaras Sutcu Imam University students agree more with the mentioned statements.

\subsection{Evaluation of the Reason for Choosing Accounting Programme}

Students mostly agree with the statements of "I want to learn more about firms and business management" ( $\overline{\mathrm{X}}=3,81)$, "I want to learn more about Accounting" $(\overline{\mathrm{X}}=3,75)$, "I want to work in the business world and view this degree as a good stepping-stone" ( $\overline{\mathrm{X}}=3,72)$.

To explore the significant differences between gender or school and the reason of students to choose accounting, Mann Whitney-U test was conducted. There is no significant differences between "gender" and reason of students to choose accounting programme (results not shown in table). Table 8 shows the significant differences between school and the statements of reason for choosing accounting programme. 
Table 8: Mann Whitney-U test between school and reason for choosing accounting programme

\begin{tabular}{|c|c|c|c|c|c|c|}
\hline Items & School & $\mathbf{N}$ & Mean & $\mathbf{U}$ & $\mathbf{Z}$ & $\mathbf{P}$ \\
\hline \multirow[t]{2}{*}{ I enjoyed subjects in school related to the degree } & KSU & 175 & 230,06 & \multirow[t]{2}{*}{18015,0} & \multirow[t]{2}{*}{$-2,883$} & \multirow[t]{2}{*}{,004* } \\
\hline & AU & 245 & 196,53 & & & \\
\hline \multirow{2}{*}{$\begin{array}{l}\text { I consider that I have the skills and abilities } \\
\text { which are suited to the study of Accounting }\end{array}$} & KSU & 175 & 232,53 & \multirow[t]{2}{*}{17583,0} & \multirow[t]{2}{*}{$-3,251$} & \multirow[t]{2}{*}{,001* } \\
\hline & $\mathrm{AU}$ & 245 & 194,77 & & & \\
\hline \multirow{2}{*}{$\begin{array}{l}\text { I want to work in the business world and view } \\
\text { this degree as a good stepping-stone }\end{array}$} & KSU & 175 & 237,59 & \multirow[t]{2}{*}{16515,0} & \multirow[t]{2}{*}{$-4,089$} & \multirow[t]{2}{*}{, $000^{*}$} \\
\hline & $\mathrm{AU}$ & 245 & 190,41 & & & \\
\hline \multirow{2}{*}{$\begin{array}{l}\text { I want to qualify as a professional accountant } \\
\text { and view this degree as a good stepping-stone }\end{array}$} & KSU & 175 & 232,80 & \multirow[t]{2}{*}{17348,0} & \multirow[t]{2}{*}{$-3,371$} & \multirow[t]{2}{*}{,001* } \\
\hline & $\mathrm{AU}$ & 245 & 193,81 & & & \\
\hline \multirow{2}{*}{$\begin{array}{l}\text { I want to learn more about firms and business } \\
\text { management }\end{array}$} & KSU & 175 & 235,81 & \multirow[t]{2}{*}{17007,5} & \multirow[t]{2}{*}{$-3,783$} & \multirow[t]{2}{*}{, $000 *$} \\
\hline & $\mathrm{AU}$ & 245 & 192,42 & & & \\
\hline \multirow[t]{2}{*}{ I want to learn more about Accounting } & KSU & 175 & 235,67 & \multirow[t]{2}{*}{17032,0} & \multirow[t]{2}{*}{$-3,743$} & \multirow[t]{2}{*}{, $000 *$} \\
\hline & $\mathrm{AU}$ & 245 & 192,52 & & & \\
\hline I am attracted by the career prospects available & KSU & 175 & 226,95 & 18559,05 & $-2,434$ &, $015 *$ to \\
\hline Accounting graduates & $\mathrm{AU}$ & 245 & 198,75 & & & \\
\hline
\end{tabular}

$* \mathrm{P}<0,05$

Table 8shows that, there are differences between "school" and the statements of "I enjoyed subjects in school related to the degree", "I consider that I have the skills and abilities which are suited to the study of Accounting", "I want to work in the business world and view this degree as a good stepping-stone", "I want to qualify as a professional accountant and view this degree as a good stepping-stone", "I want to learn more about firms and business management", "I want to learn more about Accounting" and "I am attracted by the career prospects available to Accounting graduates". Kahramanmaras Sutcu Imam University students agree more with the mentioned statements.

\subsection{Evaluation of the Expectations of Students from University Education}

Students mostly agree with the statements of "To learn about new ideas" $(\overline{\mathrm{x}}=4,28)$, "To increase my self-esteem and self-confidence" $(\overline{\mathrm{X}}=4,26)$ and "To broaden my horizons " $(\overline{\mathrm{X}}=4,15)$.

To determine the significant differences between gender or school and accounting student's expectations from university education, Mann Whitney- $U$ test was conducted in Table 9 and Table 10.

Table 9: Mann Whitney-U Test between gender and expectations of students from university education

\begin{tabular}{|c|c|c|c|c|c|c|}
\hline Items & Gender & $\mathbf{N}$ & Mean & $\mathbf{U}$ & $\mathbf{Z}$ & $\mathbf{P}$ \\
\hline \multirow[t]{2}{*}{ To increase my self-esteem and self-confidence } & $\mathrm{M}$ & 190 & 196,74 & 19235,0 & $-2,315$ &, $021 *$ \\
\hline & $\mathrm{F}$ & 230 & $\mathbf{2 2 1 , 8 7}$ & & & \\
\hline \multirow[t]{2}{*}{ To learn about new ideas } & M & 190 & 188,71 & \multirow{2}{*}{\multicolumn{2}{|c|}{$17710,0-3,665$}} &, $000 *$ \\
\hline & $\mathrm{F}$ & 230 & 228,50 & & & \\
\hline
\end{tabular}




\begin{tabular}{lllllll|} 
& & & & & & \\
To learn about new cities & M & 190 & 192,75 & 18477,0 & $-2,943$ &, $003 *$ \\
\hline
\end{tabular}

$* \mathrm{P}<0,05$

According to Table 9, there are differences between "gender" and the statements of "To increase my self-esteem and self-confidence", "To learn about new ideas" and "To learn about new cities". Female students agree more with the mentioned statements.

Table 10: Mann Whitney-U Test between school and expectations of students from university education

\begin{tabular}{|c|c|c|c|c|c|c|}
\hline Items & School & $\mathbf{N}$ & Mean & $\mathbf{U}$ & $\mathbf{Z}$ & $\mathbf{P}$ \\
\hline \multirow[t]{2}{*}{ To develop new skills } & KSU & 175 & 227,58 & 18848,0 & $-2,601$ & ,009* \\
\hline & $\mathrm{AU}$ & 245 & 198,30 & & & \\
\hline \multirow[t]{2}{*}{ To increase my self-esteem and self- Confidence } & KSU & 175 & 223,80 & 19109,5 & $-2,081$ &, $037 *$ \\
\hline & $\mathrm{AU}$ & 245 & 201,00 & & & \\
\hline
\end{tabular}

$* \mathrm{P}<0,05$

According to Table 10, there are differences between "school" and the statements of "To develop new skills" and "To increase my self-esteem and self-confidence". Kahramanmaras Sutcu Imam University students agree more with the mentioned statements.

\subsection{Evaluation of the Academic Confidence}

Students mostly agree with the statement of "Your ability to handle the course material" $(\overline{\mathrm{X}}=3,71)$.

To explore the significant differences between gender or school and academic confidence, Mann Whitney-U test was conducted. There is no significant differences between "gender" and the academic confidence of participants (results not shown in table). Table11 shows the significant differences between School and Academic Confidence of accounting and tax applications programme students.

Table 11: Mann Whitney-U Test between school and academic confidence of accounting and tax applications programme students

\begin{tabular}{|c|c|c|c|c|c|c|}
\hline Items & School & $\mathbf{N}$ & Mean & $\mathbf{U}$ & $\mathbf{Z}$ & $\mathbf{P}$ \\
\hline \multirow[t]{2}{*}{ Your ability to handle the course material } & KSU & 175 & 224,60 & 18969,5 & $-2,098$ &, $036 *$ \\
\hline & $\mathrm{AU}$ & 245 & 198,30 & & & \\
\hline \multirow{2}{*}{$\begin{array}{l}\text { Your ability to achieve results in the top } 10 \% \text { of } \\
\text { your class }\end{array}$} & KSU & 175 & 227,30 & 18497,5 & $-2,492$ &, $013 *$ \\
\hline & AU & 245 & 198,50 & & & \\
\hline
\end{tabular}

$* \mathrm{P}<0,05$

According to Table 11, there are differences between "school" and the statements of "Your ability to handle the course material" and "Your ability to achieve results in the top \%10 of your class". Kahramanmaras Sutcu Imam University students agree more with the mentioned statements. 


\subsection{Relationships with Academic Performance}

It was aimed to determine the relationships with gymnasium graduation grade, programme first semester average mark, interest in accounting as professional career and financial accounting 1 grade.

Correlation analysis is performed to see the relation between gymnasium graduation grade, interest in accounting as professional career and programme first semester average mark with Financial Accounting I Grade. Table 12 shows that there is a positive high relation between Financial Accounting 1 Grade and programme first semester average mark. Additionally, there is also significant positive relation between interest in accounting as professional career and Financial Accounting I Grade, and also between interest in accounting as professional career and programme first semester average mark.

Table 12: Correlation analysis of gymnasium graduation grade, interest in accounting as professional career and programme first semester average mark with financial accounting I grade

\begin{tabular}{|lllc|}
\hline \multicolumn{1}{|c|}{ Items } & $\begin{array}{l}\text { Gymnasium graduation } \\
\text { Grade }\end{array}$ & $\begin{array}{c}\text { Programme first semester } \\
\text { average mark }\end{array}$ & $\begin{array}{c}\text { Interest in accounting } \\
\text { as professional career }\end{array}$ \\
\hline Financial Accounting 1 Grade & $0,157^{* *}$ & $0,570^{* *}$ & $0,276^{* *}$ \\
& 0,001 & 0,000 & 0,000 \\
Gymnasium graduation Grade & $0,155^{* *}$ & & $0,227^{* *}$ \\
& 0,001 & & 0,000 \\
Programme first semester average & & & \\
mark & & \\
** Correlation is significant at the 0.01 level (2-tailed). & \\
\hline
\end{tabular}

\section{Conclusions and Recommendations}

As the globalization of education accelerates, there is a growing need to develop an understanding of the factors that influence student learning within the context of accounting education. One of the most important conditions for ensuring quality in higher education is to respond the students' demands and expectations completely.

This paper examines the perceptions of first-year accounting students as they commence their study of accounting at Akdeniz University and Kahramanmaras Sutcu Imam University in Turkey. The aim of this study is to determine students' motivation levels, expectations from high education, reason to choose the programme, preparedness of university education, expectations from university education and academic confidences. The study also explores the influence of these antecedent variables on academic performance in the first accounting module.

More than half of the students are interested in accounting as Professional career. Results show that Kahramanmaras Sutcu Imam University students have more interest in accounting career than Akdeniz University students.

The result of the evaluation of motives for attending university shows that female students agree more with some statements than male students; they declare that the university degree will bring 
new opportunities in the future, enable getting a good job and meet the education requirements for their career while it is developing their knowledge and skills and improving their self-belief and self-confidence.

Evaluation of preparedness of accounting students for university shows that female students significantly agree more with following statements than male students. These statements are female students are willing to ask help from their lecturers, confident about their ability to complete written assignments and able to evaluate their own progress.

Evaluation of expectations of students from university education shows that female students have more positive ideas about university than male students. They state that the university education will increase their self-esteem and self-confidence and, they will learn about new ideas and new cities by this education.

There is a relation between interest in accounting as professional career and accounting 1 grade. First semester average mark shows that the willingness of accounting as a career influence the grades positively.

As a result, Kahramanmaras Sutcu Imam University students rated higher than Akdeniz University students in some statements which motives for attending university, preparedness for university, and reason for choosing accounting programme. It can also be mentioned that female students and Kahramanmaras Sutcu Imam University students have stronger motives and higher expectations for entering higher education.

Byrne and Flood (2005) stated that students have been entering accounting programs with various academic backgrounds and preparation levels which cause a need for accounting educators to develop better understanding of the experiences that students bring to their learning. It is necessary to find specific teaching techniques for the students to motivate them to participate to learning process and also to collaborate with business practice to make the profession attractive to them.

The limitation of this study is that it was undertaken in only two vocational high school programmes of only two universities. In the future more than two universities' vocational high school students could be participants of this kind of study. There is also some possibility that some respondents might have a bias toward providing average or non-committal answers to the questions in the questionnaire.

\section{References}

[1] Abdulrahman Ali Al-Twaijry. (2010). "Student Academic Performance In Undergraduate Managerial-Accounting Courses."Journal Of Education For Business, 85, 311-322. Doi: $10.1080 / 08832320903449584$.

[2] Jose L. Arquero, Marann Byrne, Barbara Flood and Jose Maria Gonzalez. (2009). "Motives, Expectations, Preparedness and Academic Performance: A Study Of Students Of Accounting At A Spanish University.” Revista De Contabilidad - Spanish Accounting Review, 12(2), 279-299.

[3] Marann Byrne And Barbara Flood. (2005). "A Study Of Accounting Students' Motives, Expectations And Preparedness For Higher Education."Journal Of Further And Higher Education,29(2), 111-124. 
[4] Marann Byrne And Barbara Flood. (2007). "Exploring the Antecedents of Learning Approaches: A Study of International Business Students." International Journal Of Management Education, 6(2), 44-62.

[5] Marann Byrne And Barbara Flood. (2008). "Examining the Relationships Among Background Variables and Academic Performance Of First Year Accounting Students At An Irish University." Journal Of Accounting Education, 26, 202-212.

[6] Zafer Celik. (2012). "The Impacts of Bologna Process on European Higher Education Systems. "Journal of Higher Education And Science, 2 (2), 100-105. Doi: 10.5961/Jhes.2012.038

[7] Mehmet Gencturk. (2007). "Meslek Yuksekokulu Ogrencilerinin Mezun Olduklari Lise Turunun Ve Ogretim Seklinin Muhasebe-Finans Derslerindeki Basariya Etkisi." Muhasebe Ve Finansman Dergisi, 35, 178-185.

[8] Higher Education Law, No:2547. (1981).

Http://Www.Mevzuat.Gov.Tr/Mevzuatmetin/1.5.2547.Pdf

[9] Zekai Ozturk And Ebrar Zeynep Ilıman (2015). "Saglik Yonetimi Ve Isletmeciligi Bolumunde Okuyan Ogrencilerin Bolumu Tercih Nedenleri Ile Beklenti Ve Motivasyon Duzeyleri Uzerine Bir Arastirma." Hitit Universitesi Sosyal Bilimler Enstitusu Dergisi, 8(1), 71-93.

[10] Emin Zeytinoglu. (2012). "Muhasebe Bolumu Ogrencilerinin Motivasyonu Ve Beklentileri Uzerine Bir Arastirma: Dumlupinar Universitesi Ornegi." Muhasebe Ve Finansman Dergisi, 53, 103-116.

\footnotetext{
*Corresponding author.

E-mail address: angay@ akdeniz.edu.tr
} 